\title{
Criminal Liability and Crime and Punishment Proportionality in the Crime of Legal Entities
}

\author{
Samira Soltani ${ }^{1} \&$ Ahmad Ramazani $^{2}$ \\ ${ }^{1}$ Kish International Branch, Islamic Azad University, Kish, Iran \\ ${ }^{2}$ Science and Culture University, Iran \\ Correspondence: Samira Soltani, Kish International Branch, Islamic Azad University, Kish, Iran. E-mail: \\ samirasoltani185@yahoo.com
}

Received: June 17, 2016x Accepted: July 13, $2016 \quad$ Online Published: July 31, 2016

doi:10.5539/jpl.v9n6p61

URL: http://dx.doi.org/10.5539/jpl.v9n6p61

\begin{abstract}
One of the innovations of Islamic Penal Code in 2013 was to accept criminal liability of legal entities. By accepting criminal liability of legal entities, the way to punish them is arisen. As a legal person cannot commit any crime, any punishments are not applicable to them. Accordingly, Article 20 of this Law enumerated a list of penalties applicable to legal persons and it was tried to use penalties in accordance with the legal entities to deal with them. Punishments such as dissolution, confiscation, cash fine, announcement of the judgment, Diyeh, social and economic exclusion; such as a ban on business activities, prohibition of the public invitation to raise capital and ban from drawing business documents listed in Article 20 and Article 14, are a set of punishments which relatively different from usual punishment for individuals. These penalties are relative diversity, but what is objectionable is that the details and conditions of implementation of each of these punishments are not clear. If legislator described the details exactly or provided the condition to require the adoption of The Executive Bylaw of the punishment, it would be better. Given that all the points and issues about penalties for legal persons are not stated in this law as well as ambiguities in the law for a comprehensive definition of legal person, the way to implement main and supplementary punishments, In this study it was tried to evaluate and criticize the legal entities penalties including main and supplementary ones and their grading.
\end{abstract}

Keywords: Legal entities, criminal liability, crime, crime and punishment proportionality

\section{Introduction}

Criminal liability of legal entities expresses community responses to it shown as punishments. Obviously, given the different nature of the legal entities to individuals, penalties applicable to these persons should also be different from individuals. Article 20 of Islamic Penal Code determines the penalties dedicated to legal entities, this article states that:

If a legal entity according to article 143 of the law is recognized liable, given the severity of the crime and its harmful consequences will be sentenced to one to two of the following, this will not prevent the penalty for the individual:

a) The dissolution of the legal entity, b) the confiscation of the entire property, c) ban of one or more social or occupational activities permanently or for a maximum period of 5 years, d) prohibition of the public invitation to raise capital permanently or for a maximum period of 5 years, e) and ban from drawing business documents for a maximum period of 5 years, $\mathrm{f}$ ) cash fine, $\mathrm{g}$ ) announcing the sentence by the media, ... All of these punishments as mentioned in the note of Article 14, are of the type of Tazir punishments recognized and classified in Article 19 and according to the same article, each one placed in one of the 8 categories; therefore, the court in sentencing for legal entities, will comply with the provisions of Article 18. At the top of Article 20 it is also expressed that legal entity according to the severity of the crime and its detrimental consequences will be sentenced to one to two of the punishments referred to in Article; therefore, the criminal judge while sentencing should consider severity and weakness of crime and the damage that has been obtained from it.

Provisions relating to Tazir punishments such as discounts, falling and ... will be also applied to them based on the case with regard to the nature of legal entities. Another important point in the article is that the judge can sentence a legal entity to more than one penalty and a maximum penalty of two punishments referred to in 
Article. Diyeh is also another penalty in the provision of Article 14 applicable to legal entities. But the question is arisen that given the ambiguity in the details and conditions of each of the punishment of how their implementation would be? In this article as well as answering this question, punishments applicable to legal entities under three categories of financial penalties, punishments and other penalties depriving or limiting rights will be studied and balance or proportion of punishments applicable to offenses committed by of legal entities will be evaluated.

\section{The Concept of Legal Entity}

In scientific and legal language "personality" means to have the ability and capacity to own the rights and obligations and to implement and enforce them immediately or by someone else. In terms of law, the legal entity is one who could get the right and responsibility of the task and is able to implement it. Since right and duty are of legal issues the situation in person is called "legal personality". In fact legal entity is a group of persons or interest of the public interest that the rules put it in judgment of natural person and rights and obligations subject (Jafari Langrudi, 1864). In other words, legal entity is a person with a specific animus described by legal entities controlling it, however, his activities is different from the activities of individuals controlling it. Legal entity in this general concept includes all legal creatures with rights and duty except a human being (Jafarzadeh, 1999).

\section{The Theoretical Foundations of Criminal Liability Legal Entities}

Committing a crime by all natural and legal entities requires the realization of its material and spiritual elements; but as we all know, legal entities have no objective existence by which commit the material side of the crime and have spiritual side of the crime. Criminal law relies on an individualistic approach of liability. The reason of existing criminal law, the definition and the elements of crime, criminal liability and its determinants and performance quality of criminal provisions are among the areas that are severely affected and are subject to individual analysis (Abdullahi 2010). Naturally, in this approach, attributing the crime to legal entity expressing criminal liability of legal entities will faced serious obstacles, but the main obstacle in the way is the fault of documents which is difficult to legal entities. Michael Moore considers two principles of rationality and autonomy in the document fault as its reason (For further reading, see Moore 1985). In some countries the criminal liability of legal entities was designated based on the theory of "mastermind". This theory is based on a hypothetical view of legal entities and for legal entities by itself is not directly attached to criminal liability and it is based on the assumption that legal entities commit an offense through their individual representatives, therefore, it is looking to obtain individual criminal fault and assigning it to a legal entity. This theory is called as the theory of identification (Clarkson 2011).

Another theory accepted in some countries is "superiors or employers liability" or criminal liability of legal entities results from their failure to supervise and control. According to this theory in cases where due to lack of proper supervision and control over the actions of subordinates a crime happens, legal entity will have criminal liability of for the staff's offenses. Under Iranian law, Article 19 of cyber-crime laws (Article 747 of Islamic Penal Code 1996) both theories are together accepted. In some paragraphs criminal liability of legal entity is based on the theory of mastermind and in some cases is based on the superiors or employers liability theory (For further reading, see Rafizadeh, 2013).

Islamic Penal Code in 2013 which is the main point of our discussion, in Article 143 by providing the representative principles accepted mastermind theory. However, this theory is accepted about sentencing to Tazir sentences of Article 20. But in sentencing to Diyeh according to the note of article 14, the superiors or employers liability theory is accepted. According to this article:

Legal entity has criminal liability If is a legal representative of legal entity committed a crime in their name or for their benefit. The adoption of this theory limits the circle of criminal liability of legal entities; because only crimes committed by the legal representative, is attributable to the legal entity. Setting the criminal liability of legal persons in this way may be defensible; because when Diyeh and compensation is concerned, the legislator greatly rules to the responsibility of the legal entity and accepts the responsibility of superiors or employer's liability and consider the victim's rights. The above point in Article 143 is that the criminal liability of legal entity does not negate individual's criminal responsibility committed the crimes. All the elements of crime both material and spiritual mentioned in law should be first affirmed by the legal representative and their crime was proven in order to attribute the crime to the legal entity. Thus, either the legal representative or legal entity commits an offense and sentence to legal punishments.

Crimes attributable to legal entities

In Article 143 of the Islamic Penal Code of Iran, the criteria to accept the criminal liability is generally stated and 
the crimes which can be committed by these persons are not recognized and it seems general rule of criminal responsibility is accepted. However, by deeper investigation some crimes can be separated from some of the crimes which can be committed by legal entities. Legislator has divided crimes based on their punishments mentioned in various books of Islamic Penal Code, Hadd in note of Article 14 and Article 20, are the penalties applicable to legal entities not mentioned; therefore, the crimes punishable by Hadd are out of the scope of crimes committed by legal entities. This issue given to the nature of the crime oriented person results in Hadd and its punishments (stoning, killings, floggings, etc.) are applicable to them is normal. It may be said that if for example a company is established to do illegal acts such as prostitution and works in this field why the Company should not be and sentenced to one of the penalties referred to in Article 20 on the same charges. Punishments mentioned in Article 20 are kind of Tazir punishment and it is usually applicable to Tazir crimes and not to crimes punishable by Hadd.

At the top of Article 20 is also provided that according to the severity of the crime and its harmful consequences, the criminal will be sentenced to one of these punishments by the judge. On the other hand it is known that in our Penal Code Hadd crimes follow specific system that has the least flexibility; for example, the perpetrators of these crimes should be condemned only legal Jurisprudential and legal penalties and other penalties such as those mentioned in Article 20 cannot be applied to them. Moreover, in determining the punishment of the crimes, the severity of the crime and the devastating results obtained and things of this sort has no effects; therefore, it is not possible to condemn legal entities for this crime in criminal justice in Iran. It is natural that in such cases the court sentences individuals committing Hadd crimes to legal punishments provided in law and it is possible to punish a legal entity involved in the crime under Article 23 and as supplemental punishment to an individual or arrest them under Article 215 and as a means of committing a crime. However, due to the Hadd punishment for the partnership; legal entities can be sentenced to assisting in this crime and endure one of the penalties referred to in Article 20 (Sotudeh Tehrani, 2003; Safar, 1994; and Eskini, 2010).

Now the question raised is whether intentional crimes can be attributed to the legal entity? It is known that although it is hard but possible to imagine a legal entity commits intentional crimes; such that legal representative of legal entity in the interests of legal entity commits the crime intentionally or even that legal entity is essentially made up for the purpose. On the other hand about the crimes, the above-mentioned problem about the crimes punishable by Hadd does not exist.

In the crimes punishable by Hadd punishment is specified and it is not possible to impose punishments on legal entity other than the punishment prescribed in law. But for intentional crimes there are cases that destroy performing the execution against the perpetrators. In these cases, in accordance with Articles 612 and 614 of the Islamic Penal Code adopted in 1996, the one committed intentional crime is sentenced to prison instead of retaliation. Although the retaliation is a primary punishment for intentional crimes, it is not the only punishment applicable to the crimes. Therefore, in cases where the legal entity is attributable to an intentional crime, according to the non-applicability of Retaliation on legal entity, by the unity of criteria of 612 and 614 articles, the legal entity can be sentenced to Tazir punishment. Obviously, according to commitment punishment the legal entity can also be sentenced to prison penalty for committing the intentional crimes.

Tazir punishments, murder, intentional or inadvertent body injuries are the crimes by which legal entities can be convicted of committing them. Obviously, in the range of Tazir punishment the nature of the legal entities should also be noted. Perhaps some crimes due to the nature of the crime oriented person are not compatible with the nature of legal entities and are not attributable to them, such as crimes against family rights and obligations mentioned in Chapter 19 of the Islamic Penal Code adopted in 1996 that have oriented person nature.

\section{Punishments Applicable to the Crimes of Legal Entities}

Community responses to the legal entities are different from their reactions against the crimes by individuals. The preventative aims in expressing the reactions are preferable to the moral purposes. It is further believed that by taking safeguarding measures appropriate with the crimes creating a dangerous situation due to the legal entity's activities should be prevented or if the person's activities are deviated from legitimate target by final sentencing their lives should be terminated. Among the criminal sanctions, there should be differences between the punishments in the proper sense on the one hand and safeguarding measures on the other. Measures such as closing the Institute or closing it temporarily as well as educational measures are social defense measures and are taken independent from the doer's responsibility. Therefore, in determining the quantity and quality of mentioned measures, the discussion was about the criminal liability of logical persons. Nowadays, it is accepted that legal entities have real and objective existence distinct from those that have formed them. Lawmakers have gradually accepted the fact that these individuals due to growing activity in various fields of cultural, social, 
political and economic and harmful effects of some actions should be held accountable within the framework of rules about what they do. It should not be neglected the point that these individuals' crimes sometimes impose very high costs to society more than the individuals' crimes. Hence, the commitment of these persons in cases of violation of the rules has not remained as compensation and with a realistic look, the field of admission of criminal liability of the persons has been provided. But this does not mean that criminal liability of these persons because the penalties for human beings cannot be applicable should be neglected and avoided their punishments, but can be similar punishments with punishments specified for others, can be executed towards them. For example, instead of imprisonment, temporary closure or instead of death, their forced dissolution should be replaced.

There are other penalties such as cash fine or confiscation of property, etc. that the possibility of imposing them against certain legal entities and uncertainty is inevitable. Other obstacles declared in accepting criminal liability of legal persons, failure to achieve the goals of punishments in the event of the imposition is criminal sanctions against the persons. About the objection it should also be said that this reasoning does not seem very correct because firstly, there may be a reasonable probability that by providing financial sanctions, stop legal entities from committing crimes in the future and even can be said that only condemnation of such persons regardless of the form of punishment has preventive and deterrent aspect. Article 20 of the Islamic Penal Code listed penalties of a legal entity and extracted each of them. Legal entities' punishments are typically Tazir punishments and the levels of the most severe to the mildest degree of punishment can be seen among them as follows (Article 19) that in many of them the legislators' goals cannot be achieved of punishment:

Grade 1

The dissolution of legal person, confiscating the property

Grade 5

A permanent ban from one or more social or occupational activities, a permanent ban from the public invitation to raise capital

Grade 6

Ban from one or more social or occupational activities for a maximum period of 5 years, ban from the public invitation to raise capital for a maximum period of 5 years, ban from drawing business documents for a maximum period of 5 years and announcing the sentence by the media. Cash fines under Article 21 are at least twice and up to four times the amount that has been set in law for crimes committed by a an individual. Therefore, its degree is function of the amount provided in law and Cash fines are between the minimum and maximum prescribed by law in a court order. The court in applying legal entities should consider the severity of the crime and its harmful consequences and is allowed to sentence legal entities to one to two penalties from seven penalties under Article 20 of the legal entities, but according to Article 22, "the dissolution of the legal entity and the confiscation of property is applied when it was created to commit a crime or by deviation from first legitimate aim changed its activities exclusively in order to commit a crime. Therefore, if the court finds that the legal entity was established to commit a crime, the court cannot choose the form of punishment and the legal entity should be sentenced to both punishments of dissolution of legal entity and confiscation of all property (not the confiscation of property). With the dissolution of legal entity other prohibitions provided in this article also occurs spontaneously. But sentencing to cash fine against the legal entity is possible when lawmakers predicted cash fines for the crimes base, the behavior of an individual. However, with dissolution and confiscation of property of legal entity the sentence to cash fines and announcing the sentence in media is not permitted.

The penalties prescribed in Article 20 are main penalties. Supplementary and consequential penalties are not applicable to legal entities. In general, the crimes and punishments of legal entities are out of the inclusion of provisions such as amnesty, passed the plaintiff, punishment rebates, because these crimes were written based on certain issues. Requiring them to bear criminal sanctions is generally considered to improve procedures and prevent them from activities that are a threat to the public interest such as the environment, health, financial markets and safety of the passengers (Ardabili, 2013). Article 747 of Islamic Penal Code determined legal entity's punishments as cash fines (three to six times the maximum cash fines for the crime committed), the temporary closure and dissolution; which means that if the maximum punishment is imprisonment up to five years in prison for computer crime, temporary closure of the case from one to nine months (in case of not repeating the offense) and from one to five years (in case of repetition of the offense) and if the maximum punishment is over five years in prison, In each case, it brings about the temporary closure of one year to three years (in case of not repeating the offense) and the dissolution of the legal person (in case of repeating the offense). 
About cash fine (Ardabil, 2013) it should be said, if it is not worthy of it, it is not very effective; because legal entities especially trading companies considers its maximum as the annual costs leads to the risk of bankruptcy of legal entities with weak financial base. Effective solution to the right is to match the level of fines with the level of income, financial resources and overall reality of legal person and this is what is properly regarded as a priority by legislators. About the imposition of fines the question is that in the case of crimes committed by a legal entity, subsidiary of the parent legal person, whose funds and assets are the basis to impose financial sanction?

It seems in this respect it should be distinguished; so that if the subsidiary legal entity has an independent identity is accountable only to its own behavior. As a result, his financial conditions are the criteria for imposing penalties not the financial condition of the main legal entity. On the contrary, if this subsidiary person has independent identity and as only a branch, is the executor of policies and guidelines of the main character, cash fines are determined on the basis of financial resources of the legal entity. However, it may be correct to criticize this solution that it fulfills the main legal entities' goals and on the contrary, it reduces the effects of financial sanctions especially deterrence. Considering that the solution easily leads to subsidiary legal entity's bankruptcy and subsequently provides members' and employees' unemployment. Comparing the first solution it faces more criticism. It is believed to predict non-financial sanctions such as the suspension of punishment (Probation) is conditional on modification of the organization (the purpose of modification of the organization is Rehabilitation. This strategy was accepted in countries like the United States of America (1984) and France (1991) (Eshtiyagh, 2007). Community service, adverse publicity, disqualification from government contract may be more appropriate approach to overcome the drawbacks and limitations of financial sanction. But about the punishment of dissolution should be added, although this type of reaction is considered based on efforts to legal entities' nature and personality; but it should be considered that due to the severe effects and serious damages imposed on consumers, shareholders, employees and workers especially leaving layoffs and unemployment, it is worth Except in special cases (such as when a legal entity has changed their policy and act purely in order to commit a crime.) the reaction should not be used and if possible the above alternatives should be used (Sharifi et al., 2013).

\section{Balance or Proportion between Crime and Punishment in Crimes of Legal Entities}

As it was said, given that only the human person as the subject of criminal law and the only topic which can be discussed in criminal liability were accepted, Obviously, all rules and protections of criminal law is also applicable to individuals. Due to this fact it can be said that the scope of criminal law is dominated by individualism and this principle is one of the strongest barriers in the way to accept the criminal liability of legal entities (Ardabil, 2013). Regarding the criminal liability for legal persons is considered as logical axioms and accessories. According to the wisdom, a balance is established between having rights and responsibility thus it is meaningless that of legal entities have rights and duties but not their responsibility. Likewise, when the CEO of a company implements a strategy and trade policy, He does not act only as an individual but as an officer and a company representative. Without referring to specific roles within the company's structure and policies, No good description of what is said or operation is possible. Therefore the argument is that human behavior is often formed by their relationships with groups and communities. Not in the sense that individual autonomy to be destroyed in the process, because people are free to free themselves from the constraints. In general, the issue is that legal entities should be held accountable in criminal and civil terms, because they themselves provide the individuals the structure to act as their police. A legal entity appoints an individual and puts them in a particular situation. The person in those situations acts something for the legal entity. Therefore, in fact the legal entity should be responsible in parallel with that person (Eshtiyagh, 2008). The fact that punishments are personal resulted in human maturity and liberal thought of scholars from different legal schools is in fact a reaction expressed against the traditions of the past about punishing criminals. According to proponents of the theory of criminal liability of legal entities, Criminal prosecution and punishment of these people, give real criminals the opportunity to escape from the punishments and this makes the main goal mislead because shareholders and workers and other innocent people suffer real losses. Therefore criminal liability of legal persons is like a shield to protect the real offenders against punishment. Hence, in any legal entities the guilty person should be found and punished. As a result, applying both financial and non-financial penalties of any kind against legal entities damages the fact that punishments are personal and finally leads to punishing innocent people may not be involved in decisions or even disagreed them (Rastin, 2003). Regarding the objection and the general principle of personal punishment the two following points are considerable:

1) The first point is that the objection people are generally not limited to legal entities. Despite the fact that this principle has been accepted by all the legislators of different legal systems but it should be acknowledged that, in practice, it is a metaphorical unrealistic assumption, because the effects of individual convictions inevitably 
influences first to family members, and then sometimes to other relatives and their fate becomes effective as well. Crime conviction to a variety of financial and other penalties deprives liberty or malfunction financial and moral damages to the family. For example, prisons cut prisoners' ties with ordinary life, family, work and friends.

This penalty is imposed to the criminal as well as to relatives, especially his wife and children and puts him in an artificial environment that is anti-social. And that is why different schools try to take measures intended to reduce the harmful effects of this type of punishment. On the other hand conviction of criminals to pay cash fine impairs the livelihood of his family and disturbs financial situation. Also, the families whose one of the members is sentenced to criminal conviction, in addition to enormous psychological suffering they personally endure, practically face of adverse reactions and in fact they are hidden actual victims of the penalties.

2) It is said that by punishing individuals, the real criminals committed the crimes escape and it makes the punishment heavy to the people not involved in the crimes. The response is that it is not without any solutions. Responsibility structure and how to carry out the punishment, should have such a guarantee that the legal entity and the person who commits the crime to be tried separately and properly and according to the amount of their responsibility and the idea of criminal liability of a legal entity does not mean to rescue real perpetrators of the crime from punishment. But the theories expressed in this regard seek to create a dual liability for the legal entity, criminal and the person committed the crime. On the other hand, that the persons constituting the legal entity and especially shareholders are often introduced innocent in this debate is not very close to the fact. Their investments and consequently their self-interest in the Legal entity should be considered. In other words, it should be imagined that if the crime was not discovered these people were involved in illicit gains resulting from it. Therefore in rejecting the objection it can be argued that each of the members and shareholders of the legal entity because of lack of care and negligence have committed a criminal error and penalties against legal persons will cause them to pay enough attention in decision-making and selecting committees and various institutions that manage it to prevent committing a crime. Then, by the way, each of the legal entities changes to a private justice system to prevent the crime before creating responsibility for the individual (Rastin, 2003). The first important step in eliminating the problem was that how a legal person can be considered a substitute for the exercise of his staff and is the greatest success in proving the criminal liability of legal persons considered.

The real problem in the way of the evolution of the criminal liability of legal entities is one the nature of the traditional crimes of criminal law in general and the other is specifically the issue of criminal intent. Most resistances in the way of accepting criminal liability of legal entities are in these two sides. Legislators believed that these persons cannot commit crimes against persons and testimony and false oath or betraying the country, because the crimes get their traits from corrupt thought of the person committed the crime and in fact they are violation of the social obligations that have been granted to individuals and a legal entity does not have any of these commitments therefore the criminal cannot be identified.

In the late 1940s, the real ushers of modern law were arisen on criminal liability of legal persons outside the scope of only material crimes and substitution responsibility and this became possible with the advent of real authentic doctrine (Ardebili, 2013). This new form of liability was based on the idea that legal entity can be judge with their directors and senior officers' actions; therefore Legal entity is personally responsible for their actions. Following these developments, lawyers define and describe the concept of crime committed by legal entities. In general, crimes by legal entities are any illegal activities through which the main perpetrator by using the form of legal entity seeks to add material benefits so that he could call them personal interests.

According to note of article 14, unintentional murder and bodily injury are attributable to legal entity and cause Diyeh from Legal entity. With the explanation that the scope of criminal liability of legal entities in terms of Diyeh is broader and only in case of establishing causality relationship between Legal entity behavior and the damage, the legal person is responsible. In fact, among the model of dual criminal liability of legal persons in different legal systems, Islamic Penal Code, based on the theory of superior liability or liability employer, stated that the possibility of sentencing these people to Diyeh is against Tazir punishments provided in Article 20. As "Duma" the famous french lawyer, any actions which results in any damages should be compensated by someone who had negligence or error else; because this act is an offense occurred even though the subject is not going to harm (Safar, 2011).

\section{Conclusion}

Accepting the criminal liability of legal entities is one of the achievements of the 1392 Penal Code. Although the legislator has not paid the crimes committed by legal entities and only one article (143) has been confined or it was preferred to consider the conditions of committing the crimes, but in some articles the legal entities penalties were paid. However, the importance of punishments of legal entities to the extent that the existence of some 
articles cannot explain all the issues related to the punishment of legal entities. The legal entities' penalties can be studied in the two groups of main and supplementary penalties. Applying supplementary penalties to legal entities according to Article 23 and the notes mentioned in it is difficult. However, in general terms there are no barriers to the consideration of supplementary penalties to legal persons. In the field of the main penalties of legal person, different penalties are considered in the criminal provisions of the countries. These penalties can be divided into different types based on the nature of the subject. According to Article 20, the main punishments of legal person are divided to the penalties depriving rights restrictive penalties, and financial penalties. According to Article 20, the main punishments of legal person are divided to penalties depriving of rights, restrictive rights and financial penalties. Legislator in Article 20 noted penalties applicable to legal entities that all of them are Tazir punishments. Iranian lawmakers in determining penalties such as determining the general rule of criminal liability of legal persons in Article 143 followed the French Penal Code. Punishments mentioned in Article 20 are of the relative diversity to deal with the criminal legal entities. This feature helps the court to choose a penalty in each case that on the one hand have the highest correlation with legal person status and on the other hand have minimal impacts on the users of legal person's services. But there is a problem in this case that the details and conditions of their implementation are not specified. In this way, ambiguous and vague codification is not good for criminal legislator. Therefore, it is suggested that on the next steps legislator separately identify how to run, detail any of the penalties and enforcement of each of them. Finally, it is worth legislators explain the issues of legal entities penalties and eliminate errors and ambiguities and by providing a clear definition of the legal person and explain objective and clear examples of legal entities and punishment appropriate to legal entities punishment to reduce challenges facing criminal liability of legal entities.

\section{References}

Ardebili, M. A. (2013). General Criminal Law (Vol. II). Tehran: Mizan publication, thirty-first print.

Eshtiyagh, V. (2007). Criminal liability of legal entities. Doctoral dissertation, School of Shahid Motahari.

Eshtiyagh, V. (2008). Criminal liability legal entities in the bill IPC. Law Journal, VII(13).

Eskini, R. (2010). Business Law: commercial documents. Tehran: publication of Samt.

Jafar Langrudi, M. J. (1984). Rights terminology. Tehran: Rastad Institute publication.

Jafarzadeh, A. (2009). Authentication of legal entities. Monthly Magazine of Notary and Daftaryaran Association, 14.

Jefferson, M. (2001). Criminal law (5th ed.). London, Longman Pearson Education Limited.

Moore, M. (1985). The Moral and Metaphysical Sources of the CriminalLaw, in Pennock and chapman, 11.

Rafizadeh, A. (2013). Criminal liability of legal entities of public law, criminal law and criminology. Master's thesis, Law School, Shahid Beheshti University.

Rastin, M. (2003). Businessman's Criminal Code (2nd ed.). Tehran: Faculty of Administrative Sciences and Business Administration.

Safar, M. J. (1994). Legal entity (1st ed.). Tehran: Dana publication.

Sharifi, M., habibzadeh, M. J., Eisaei Tafreshi, M., \& Farajiha, M. (2013). Changes of criminal liability of legal entities in Iran. Justice Law Journal, 82.

Sotudeh Tehrani, H. (2003). Business Law (Vol. 1). Tehran: publication of Dadgostar.

Wells, C. (2001). Corporations and Criminal Liability (2nd ed.). Oxford, Oxford University Press. http://dx.doi.org/10.1093/acprof:oso/9780198267935.001.0001

\section{Copyrights}

Copyright for this article is retained by the author(s), with first publication rights granted to the journal.

This is an open-access article distributed under the terms and conditions of the Creative Commons Attribution license (http://creativecommons.org/licenses/by/4.0/). 